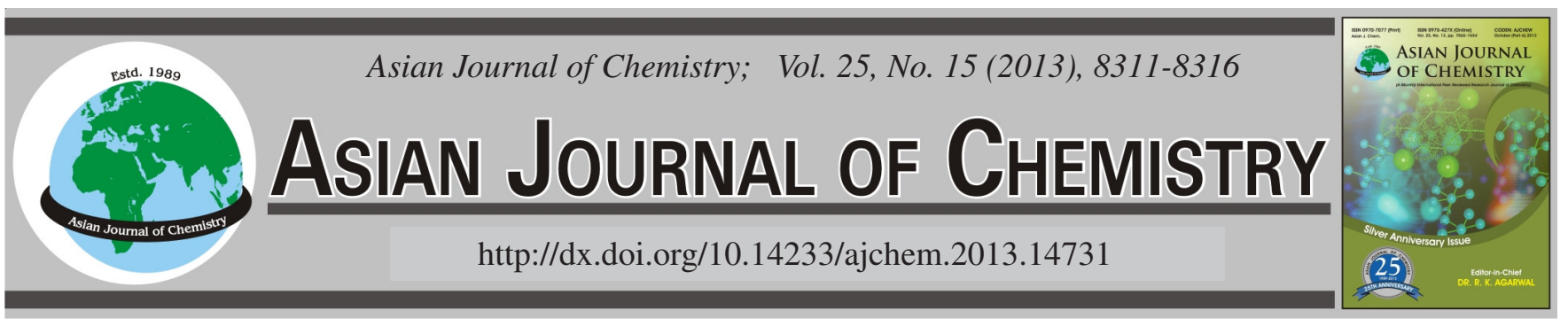

\title{
in vitro Antioxidant Activity and Total Phenolic Content of Various Extracts of Satureja hortensis L. Collected from Turkey
}

\author{
Yesim Yesiloglu ${ }^{1, *}$, LatifSAH Sit $^{1}$ and Ismail KILIC ${ }^{2}$
}

${ }^{1}$ Department of Chemistry, Faculty of Science, Trakya University, Edirne, Turkey

${ }^{2}$ Faculty of Education, Trakya University, Edirne, Turkey

*Corresponding author: Fax: +90 284 2358754; Tel: +90 284 2359592; E-mail: yesimyesiloglu@ trakya.edu.tr

\section{INTRODUCTION}

Free radicals have been claimed to play an important role in affecting human health by causing several diseases including cancer, hypertension, heart attack and diabetes. Dietary intake of phenolic compounds correlates with reduced coronary heart disease, cancer mortality and protective in many healthrelated properties, such as antioxidant, anticancer, antiviral and antiinflammatory activities ${ }^{1-3}$. Plants and their products are rich sources of phytochemicals and have been found to possess a variety of biological activities including antioxidant potential $^{4,5}$.

Satureja hortensis L. contains high levels of carvacrol, paracymene, ascorbic acid, tannin, borneol, monoterpene, diterpene, sesquiterpene and essential oils. It is an herbadeous perennial plant of the Lamiaceae family and a grassy plant with pink flowers and small green to yellow seeds, which grows in Trakya region of Turkey and South Europe. Satureja hortensis is generally known under the names "çibrika or geyikotu" and is widely used as spice in Turkey. S. hortensis herbs are used to treat stomach ache in Turkish folk medicine. In addition, this herb is used as diuretic, savory and for quinsy. Furthermore, it had an analgesic effect.

This study can help in food industry as a natural compound for antioxidant activity, which might be used as an alternative to synthetic antioxidants since it is environmentally friendly and safe for consumption.

\section{EXPERIMENTAL}

Linoleic acid, $\alpha$-tocopherol, potassium persulfate, nicotinamide adenine dinucleotide (NADH), butylated hydroxyanisole (BHA), butylated hydroxytoluene (BHT), nitroblue tetrazolium (NBT), phenazine methosulfate (PMS), 1,1-diphenyl-2-picrylhydrazyl (DPPH), gallic acid, pyrocatechin, gallic acid and 3-(2-pyridyl)-5,6-bis(4-phenyl-sulfonic acid)-1,2,4triazine (ferrozine) were obtained from Sigma (Sigma-Aldrich $\mathrm{GmbH}$, Sternheim, Germany).

Ammonium thiocyanate, ferrous chloride, polyoxyethylenesorbitan monolaurate (Tween-20), trichloroacetic acid (TCA), ethanol (EtOH) and acetone were purchased from Merck. All other chemicals used were in analytical grade and obtained from either Sigma-Aldrich or Merck.

Fresh leaves and flowers of $S$. hortensis were purchased from a traditional market at Edirne City (Edirne, Turkey). Plant materials were washed with distilled water and dried at room temperature. The dried plant was stored in $-20^{\circ} \mathrm{C}$ until used.

Preparation of extracts: For water extraction, dried plant $(25 \mathrm{~g})$ was put into a fine powder in a mill and was mixed with $500 \mathrm{~mL}$ boiling water by magnetic stirrer for $15 \mathrm{~min}$. Then, the extract was filtered over Whatman No. 1 paper. The filtrates were frozen and lyophilized in lyophilizator at $5 \mu \mathrm{m} \mathrm{Hg}$ pressure at $-50^{\circ} \mathrm{C}$ (Labconco, Freezone $1 \mathrm{~L}$ ). Similarly, dried plant $(25 \mathrm{~g})$ was put into a fine powder in a mill and was mixed with $500 \mathrm{~mL}$ acetone or ethanol. The residue was re-extracted 
until extraction solvent became colourless. Each of the extracts obtained were dried using a rotary evaporator (Buchi R-200, Switzerland). The dry extract obtained with each solvent was weighed. The percentage yield was expressed in terms of air dries weight of plant material. All the extracts were kept at $-20{ }^{\circ} \mathrm{C}$ and were dissolved in water or solvent before use.

Determination of total phenolic compounds: Total phenolics in S. hortensis extracts were determined with FolinCiocalteau reagent, according to the method of Slinkard and Singleton ${ }^{6}$. Briefly, $1 \mathrm{~mL}$ of the $S$. hortensis extracts (20-100 $\mu \mathrm{g} / \mathrm{mL}$ ) was transferred into test tubes and their volumes made up to $46 \mathrm{~mL}$ with distilled water. After addition of $1 \mathrm{~mL}$ FolinCiocalteau reagent and $3 \mathrm{~mL} 2 \% \mathrm{Na}_{2} \mathrm{CO}_{3}$ solution, tubes were vortexed and then allowed to stand for $2 \mathrm{~h}$ intermittent shaking. The absorbance was measured at $760 \mathrm{~nm}$ in a spectrophotometer (Shimadzu UV-1601, Japan). The total phenolic compounds in the $S$. hortensis extracts were calculated as mg of catechol equivalent from the calibration curve and as mg catechol equivalents per $g$ of extracts. The data were presented as the average of triplicate analyzes.

Determination of total flavonoid content: Total flavonoid content was determined by using a method described by Wang et $a l^{7}$ with minor modification using catechin as standard flavonoid compound. Briefly, $10 \mathrm{~mL}$ of each extract (1000 $\mu \mathrm{g} / \mathrm{mL})$ or $(+)$-catechin standard solution $(20-100 \mu \mathrm{g} / \mathrm{mL})$ was mixed with $1 \mathrm{~mL}$ of a $5 \%$ sodium nitrite solution. After $6 \mathrm{~min}$, $1 \mathrm{~mL}$ of a $10 \%$ aluminium nitrate solution was added and the mixture was allowed to stand for a further 6 min before 10 $\mathrm{mL}$ of a $4.3 \% \mathrm{NaOH}$ was added. The mixture was brought to $25 \mathrm{~mL}$ with distilled water and mixed well. After $15 \mathrm{~min}$, the absorbance was measured at $510 \mathrm{~nm}$ using a spectrophotometer. Results were expressed as the average of triplicates. The results were expressed as the mean $( \pm$ SD) $\mathrm{mg}$ of $(+)$ catechin equivalents per $\mathrm{g}$ of extract.

DPPH radical scavenging activity: The DPPH (1,1diphenyl-2-picrylhydrazil) radical scavenging activity of the $S$. hortensis extracts was measured according to the procedure described by Shimada et al. ${ }^{8}$. Briefly, $0.1 \mathrm{mM}$ solution of $\mathrm{DPPH}^{\bullet}$ in ethanol was prepared and $1 \mathrm{~mL}$ of this solution was added to $3 \mathrm{~mL}$ of $S$. hortensis extracts at different concentrations $(20-100 \mu \mathrm{g} / \mathrm{mL})$. The mixture was shaken vigorously and allowed to stand in the dark at room temperature for 0.5 $\mathrm{h}$. The decrease in absorbance of the resulting solution was then measured spectrophotometrically at $517 \mathrm{~nm}$ against ethanol. All measurements were made in triplicate and averaged. The DPPH radical scavenging activity was calculated using the following equation:

DPPH radical scavenging activity $(\%)=\left(\frac{\mathrm{A}_{0}-\mathrm{A}_{1}}{\mathrm{~A}_{0}}\right) \times 100$

$\mathrm{A}_{0}$ is the absorbance of the control and $\mathrm{A}_{1}$ is the absorbance of the sample.

Reducing power: The reducing power of the S. hortensis extracts was determined according to the method described by Oyaizu ${ }^{9}$. Different amounts of extracts $(20-100 \mu \mathrm{g})$ in $1 \mathrm{~mL}$ of distilled water were mixed with $2.5 \mathrm{~mL}$ of $0.2 \mathrm{M}$ phosphate buffer $(\mathrm{pH}=6.6)$ and $2.5 \mathrm{~mL}$ potassium ferricyanide $(1 \%)$ and then the mixture was incubated at $50{ }^{\circ} \mathrm{C}$ for $0.5 \mathrm{~h}$. After- wards, $2.5 \mathrm{~mL}$ of trichloro acetic acid (10\%) was added to the mixture to stop the reaction, then the mixture was centrifuged at $3000 \mathrm{rpm}$ for $10 \mathrm{~min}$. The supernatant $(2.5 \mathrm{~mL})$ was mixed with $2.5 \mathrm{~mL}$ distilled water and $0.5 \mathrm{~mL} \mathrm{FeCl}_{3}(0.1 \%)$ and then absorbance was measured at $700 \mathrm{~nm}$ in a spectrophotometer. The reducing power of the tested samples increased with the absorbance values.

Iron(II) chelation activity: Ferrous ion $\left(\mathrm{Fe}^{2+}\right)$ chelation by $S$. hortensis extracts was estimated by the method of Dastmalchi et al. ${ }^{10}$. Briefly, extracts $(20-100 \mu \mathrm{g} / \mathrm{mL})$ were added to $0.05 \mathrm{~mL}$ of $2 \mathrm{mM} \mathrm{FeCl}_{2}$ solution. The reaction was initiated by the addition of $0.2 \mathrm{~mL}$ of $5 \mathrm{mM}$ ferrozine solution and the mixture was shaken vigorously and left standing at room temperature for $10 \mathrm{~min}$. Absorbance of the solution was then measured spectrophotometrically at $562 \mathrm{~nm}$. All test and analyses were run in triplicate and averaged. The percentage of inhibition of ferrozine- $\mathrm{Fe}^{2+}$ complex formation was calculated using the formula given bellow:

$$
\text { Metal chelating activity }(\%)=\left(\frac{\mathrm{A}_{0}-\mathrm{A}_{1}}{\mathrm{~A}_{0}}\right) \times 100
$$

$\mathrm{A}_{0}$ is the absorbance of the control and $\mathrm{A}_{1}$ is the absorbance of the sample.

$\mathrm{H}_{2} \mathrm{O}_{2}$ scavenging activity: The hydrogen peroxide scavenging ability of $S$. hortensis extracts was determined according

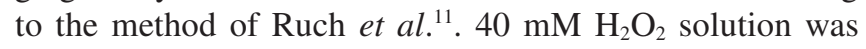
prepared in phosphate buffer $(\mathrm{pH}=7.4)$ and $0.6 \mathrm{~mL}$ of this solution was added to extracts $(20-100 \mu \mathrm{g} / \mathrm{mL})$ in distilled water. The absorbance value of the reaction mixture was recorded at $230 \mathrm{~nm}$. The percentage of $\mathrm{H}_{2} \mathrm{O}_{2}$ scavenging of extracts and standard compounds was calculated as:

$$
\mathrm{H}_{2} \mathrm{O}_{2} \text { scavenging activity }(\%)=\left(\frac{\mathrm{A}_{0}-\mathrm{A}_{1}}{\mathrm{~A}_{0}}\right) \times 100
$$

$\mathrm{A}_{0}$ is the absorbance of the control and $\mathrm{A}_{1}$ is the absorbance of the sample.

Superoxide anion radical scavenging activity: Measurement of superoxide anion scavenging activity of $S$. hortensis extracts was based on the method described by Liu et al. ${ }^{12}$ with slight modification. Briefly, the superoxide radicals were generated in $3 \mathrm{~mL}$ of $16 \mathrm{mM}$ Tris- $\mathrm{HCl}$ buffer $(\mathrm{pH}=8)$ containing $1 \mathrm{~mL}$ of $50 \mu \mathrm{M}$ NBT solution, $1 \mathrm{~mL}$ of $78 \mu \mathrm{M}$ NADH solution and sample solution of $S$. hortensis extracts (20-100 $\mu \mathrm{g} / \mathrm{mL}$ ) in water. The reaction was started by adding of $1 \mathrm{~mL}$ of $10 \mu \mathrm{M}$ phenazine methosulphate solution to the mixture. The reaction mixture was incubated at $25^{\circ} \mathrm{C}$ for $5 \mathrm{~min}$ and then absorbance was measured at $560 \mathrm{~nm}$. The percentage inhibition of superoxide anion generation was calculated using the following formula:

$$
\text { Inhibition }(\%)=\left(\frac{\mathrm{A}_{0}-\mathrm{A}_{1}}{\mathrm{~A}_{0}}\right) \times 100
$$

$\mathrm{A}_{0}$ is the absorbance of the control and $\mathrm{A}_{1}$ is the absorbance of the sample.

Inhibition of lipid peroxidation: The total antioxidant activity of $S$. hortensis extracts was determined according to the thiocyanate method ${ }^{13}$. For stock solutions, $10 \mathrm{mg}$ of each S. hortensis extracts was dissolved in $10 \mathrm{~mL}$ water (or solvent). 
Then, the solution, which contains the same amount of $S$. hortensis extracts or standard samples $(60 \mu \mathrm{g} / \mathrm{mL})$ in $2.5 \mathrm{~mL}$ of $0.04 \mathrm{M}$ potassium phosphate buffer $(\mathrm{pH}=7)$ was added to $2.5 \mathrm{~mL}$ of linoleic acid emulsion in $0.04 \mathrm{M}$ potassium phosphate buffer $(\mathrm{pH}=7)$. Fifty millilitres linoleic acid emulsion contained $175 \mu \mathrm{g}$ Tween-20, $155 \mu \mathrm{L}$ linoleic acid and $0.04 \mathrm{M}$ potassium phosphate buffer $(\mathrm{pH}=7)$. On the other hand, $5 \mathrm{~mL}$ control was composed of $2.5 \mathrm{~mL}$ linoleic acid emulsion and $2.5 \mathrm{~mL}$ of $0.04 \mathrm{M}$ potassium phosphate buffer $(\mathrm{pH}=7)$. The mixed solution $\left(5 \mathrm{~mL}\right.$ ) was incubated at $37^{\circ} \mathrm{C}$ in a glass flask. The peroxide level was determined by reading the absorbance at $500 \mathrm{~nm}$. This step was repeated every $10 \mathrm{~h}$ until the control reached its maximum absorbance value. The per cent inhibition of lipid peroxidation in linoleic acid emulsion was calculated by the following equation:

$$
\text { Inhibition of lipid peroxidation }(\%)=\left(\frac{\mathrm{A}_{0}-\mathrm{A}_{1}}{\mathrm{~A}_{0}}\right) \times 100
$$

$\mathrm{A}_{0}$ is the absorbance of the control and $\mathrm{A}_{1}$ is the absorbance of the sample.

Statistical analysis: Results were expressed as mean \pm standard deviation of triplicate analyses. The correlation coefficient $\left(\mathrm{r}^{2}\right)$ between the parameters tested was established by regression analysis.

\section{RESULTS AND DISCUSSION}

Extract yield (amount of total extractable compounds) and contents of total phenolics and flavonoids: Water, $\mathrm{EtOH}$ and acetone extracts prepared from $25 \mathrm{~g}$ of $S$. hortensis gave a yield of $0.185,0.048$ and $0.036 \mathrm{~g}$ extractable compounds (EC) per gram of DW, respectively (Table-1). Phenolics or polyphenols are secondary plant metabolites that are ubiquitously present in plants and plant products. Polyphenols are marker of the nutritional quality of foods. Polyphenols are known for their antioxidant activity as radical scavengers and possible beneficial roles in human health, such as reducing the risk of cancer, cardiovascular disease, other pathologies ${ }^{14}$. Plants containing high phenolic compounds can be a good source of antioxidants. For this reason, this information has led to the determination of the total phenolic content of the sample under study.

\section{TABLE-1}

TOTAL EXTRACTABLE COMPOUNDS (EC), TOTAL PHENOLIC COMPOUNDS (AS CATECHOL EQUIVALENTS) AND TOTAL

FLAVONOIDS (AS CATECHIN EQUIVALENTS) IN WATER, ETHANOL AND ACETONE EXTRACTS OF S. hortensis

\begin{tabular}{lccc}
\hline Extract & $\begin{array}{c}\mathrm{EC}^{\mathrm{a}} \\
(\mathrm{g} / \mathrm{g} \mathrm{DW})\end{array}$ & $\begin{array}{c}\text { Total phenols }(\mathrm{mg} \\
\text { catechol/g extract) }\end{array}$ & $\begin{array}{c}\text { Total flavonoids }(\mathrm{mg} \\
\text { catechin/g extract) }\end{array}$ \\
\hline Water & 0.185 & $183 \pm 0.67$ & $45.5 \pm 0.24$ \\
Ethanol & 0.048 & $116 \pm 1.85$ & $31.7 \pm 2.6$ \\
Acetone & 0.036 & $83 \pm 1.24$ & $41.7 \pm 1.8$
\end{tabular}

Values were the means of three replicates \pm standard deviation. ${ }^{\text {a }}$ Extractable compounds; DW = Dry weight.

Extracts contained high amounts of phenolic compounds. The content of total phenolic compounds is given in Table- 1 . The mean of the total phenolic content per gram of crude extract of water extract $(183 \pm 0.67 \mathrm{mg}$ catechol equivalent/g extract) was found to be higher than that of the EtOH (116 \pm
$1.85 \mathrm{mg}$ catechol equivalent/g extract) and acetone $(83 \pm$ $1.24 \mathrm{mg}$ catechol equivalent/g extract) extracts. Thus, it was concluded that water was more efficient at extracting phenolic compounds from the plant than was ethanol and acetone.

Flavonoids are natural phenolic compounds and well known antioxidants. Therefore dietary intake of flavonoidcontaining foods was suggested to be of beneficial for the preservation from free radical damage. The concentration of flavonoids in the extracts was expressed as $\mathrm{mg}$ of catechol equivalents per $\mathrm{g}$ of the extract (Table-1). In our investigation, the water extract of $S$. hortensis exhibited the highest total flavonoids content $(45.5 \pm 0.24 \mathrm{mg}$ catechin equivalent/g extract), whereas the contents obtained with $\mathrm{EtOH}(31.7 \pm 2.6$ $\mathrm{mg}$ catechin equivalent/g extract) or acetone $(41.7 \pm 1.8 \mathrm{mg}$ catechin equivalent/g extract) extracts were smaller. These amounts were comparable with results described in the literature for other extracts of plant products ${ }^{15,16}$.

DPPH radical scavenging activity: Antioxidant properties, especially radical scavenging activities, are very important due to the deleterious role of free radicals in foods and in biological systems. Excessive formation of free radicals accelerates the oxidation of lipids in foods and decreases food quality and consumer acceptance ${ }^{17}$. The model of scavenging the stable DPPH radical is a widely used method to evaluate antioxidant activities in relatively short time as compared to other methods. DPPH is a stable free radical and accepts an electron or hydrogen radical to become a stable diamagnetic molecule.

The DPPH radical scavenging activities of all the extracts of $S$. hortensis increased with increasing concentration. With regard to the $S$. hortensis extracts, Fig. 1 illustrates that the sequence for DPPH radical-scavenging ability was EtOH extract $>$ ascorbic acid $\approx$ BHA $>$ BHT $>$ water extract $>$ acetone extract $>\alpha$-tocopherol. At $60 \mu \mathrm{g} / \mathrm{mL}$, the scavenging abilities on DPPH radicals were $65.36 \pm 1.65,63.39 \pm 1.48,59.48 \pm$ $5.93,52.94 \pm 2.26,49.67 \pm 1.69,44.44 \pm 3.17$ and 35.29 $\pm 1.53 \%$ for the BHA, ascorbic acid, EtOH, acetone and water extracts, $\alpha$-tocopherol and BHT, respectively. Though the DPPH radical scavenging activities of extracts were less than those of ascorbic acid and BHA, the study revealed that extracts have free radical scavengers or inhibitors, acting possibly as primary antioxidants. It was reported that phenolics and flavonoids reduced DPPH radical by their hydrogen donating ability $^{18}$.

Table- 2 shows that the $\mathrm{EC}_{50}$ values of $\mathrm{DPPH}$ radicals scavenging for the acetone, $\mathrm{EtOH}$ and water extracts were $33.57 \pm$ $1.19,16.97 \pm 2.31$ and $15.94 \pm 1.62 \mu \mathrm{g} / \mathrm{mL}$, respectively.

Reducing power: The reducing capacity of a compound may serve as a significant indicator of its potential antioxidant activity ${ }^{19}$. Fig. 2 shows, the extent of the reduction, in terms of absorbance values at $700 \mathrm{~nm}$. The reducing power of water extract $(0.176 \pm 0.003)$, EtOH extract $(0.110 \pm 0.009)$ and acetone extract $(0.086 \pm 0.004)$ was concentration dependent and was found to be below those of ascorbic acid (0.552 \pm $0.077)$ and BHA $(0.184 \pm 0.002)$ at $100 \mu \mathrm{g} / \mathrm{mL}$. Extracts showed higher reducing power than tocopherol $(0.061 \pm 0.005)$ and BHT $(0.04 \pm 0.003)$ at the same concentration. Reducing power of extracts and standards decreased in order of ascorbic acid $>$ BHA $>$ water extract $>$ EtOH extract $>$ acetone extract 


\begin{tabular}{lccccc}
\hline & \multicolumn{5}{c}{ TABLE-2 } \\
& \multicolumn{5}{c}{ EC $_{50}$ VALUES OF DPPH RADICAL-QUENCHING ACTIVITY, REDUCING POWER, CHELATING } \\
& CAPACITY, HYDROGEN PEROXIDE AND SUPEROXIDE RADICALS OF S. hortensis EXTRACTS \\
\hline \multirow{3}{*}{ Plant extracts } & \multicolumn{5}{c}{ EC $_{50}(\mu \mathrm{gg} / \mathrm{mL})$} \\
& $\begin{array}{c}\text { Scavenging ability on } \\
\text { DPPH radicals }\end{array}$ & $\begin{array}{c}\text { Scavenging ability on } \\
\text { superoxide }\end{array}$ & $\begin{array}{c}\text { Scavenging ability on } \\
\text { hydrogen peroxide }\end{array}$ & $\begin{array}{c}\text { Reducing } \\
\text { power }\end{array}$ & $\begin{array}{c}\text { Chelating } \\
\text { power }\end{array}$ \\
\hline Water & $15.94 \pm 1.62$ & $11.37 \pm 1.66$ & $13.81 \pm 4.28$ & $42.63 \pm 3.26$ & $14.03 \pm 1.03$ \\
Acetone & $33.57 \pm 1.19$ & $40.09 \pm 0.17$ & $24.46 \pm 3.51$ & $29.28 \pm 3.15$ & $24.46 \pm 1.92$ \\
Ethanol & $16.97 \pm 2.31$ & $58.56 \pm 1.04$ & $18.77 \pm 1.74$ & $32.09 \pm 1.64$ & $18.35 \pm 2.44$ \\
BHA & $10.43 \pm 0.17$ & $12.66 \pm 0.04$ & $12.09 \pm 1.12$ & $40.02 \pm 0.03$ & $14.93 \pm 0.25$ \\
BHT & $56.71 \pm 1.82$ & $11.51 \pm 2.41$ & $12.05 \pm 2.13$ & $15.54 \pm 1.17$ & $20.14 \pm 1.09$ \\
$\alpha$-Tocopherol & $25.02 \pm 4.26$ & $19.85 \pm 1.74$ & $11.99 \pm 3.26$ & $14.96 \pm 0.52$ & $16.01 \pm 0.06$ \\
Ascorbic acid & $11.21 \pm 0.29$ & $40.29 \pm 0.03$ & $12.07 \pm 0.05$ & $46.91 \pm 2.84$ & $17.09 \pm 0.7$ \\
\hline
\end{tabular}

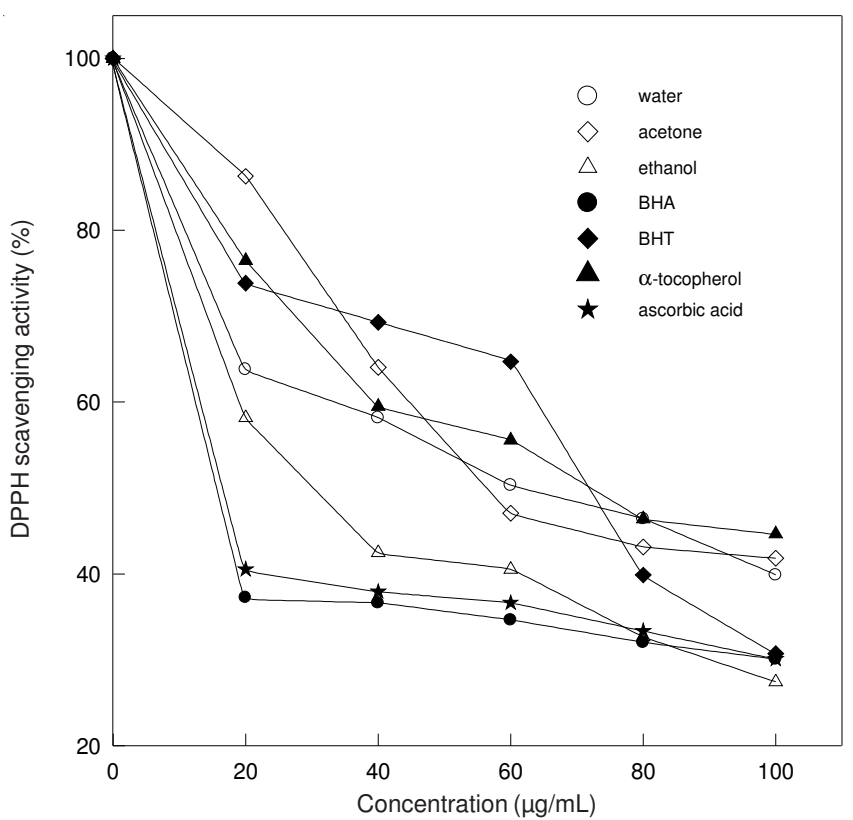

Fig. 1. DPPH radical scavenging activity of $S$. hortensis extracts. $\alpha$ Tocopherol, ascorbic acid, BHA and BHT were used as reference antioxidants. Values are means \pm SD $(n=3)$

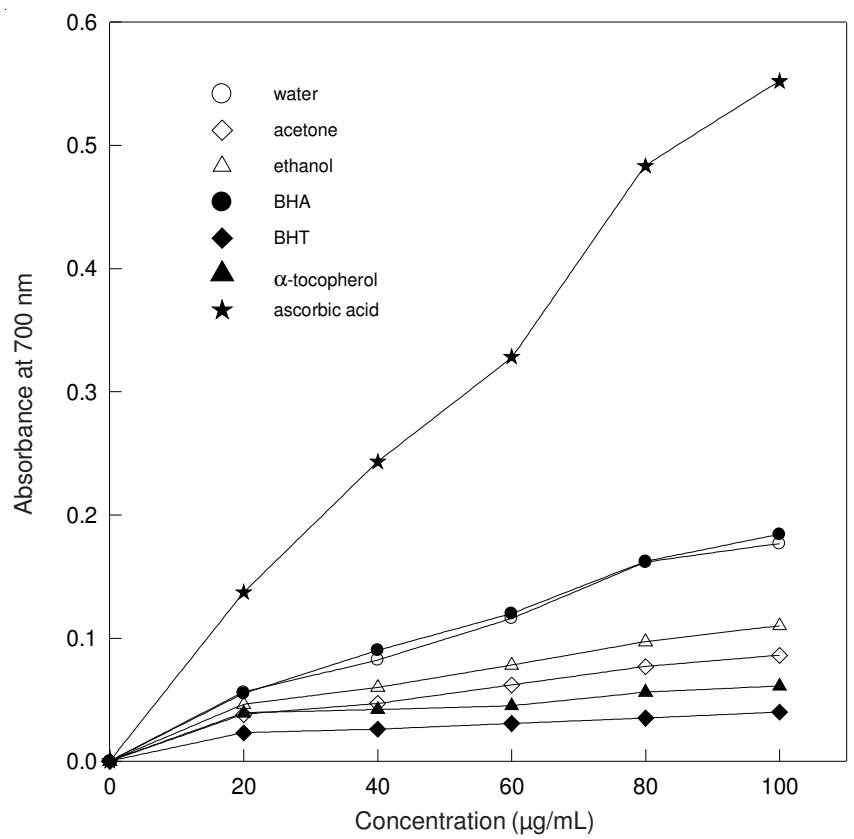

Fig. 2. Reducing power of the $S$. hortensis extracts. $\alpha$-Tocopherol, ascorbic acid, BHA and BHT were used as reference antioxidants. Values are means \pm SD $(n=3)$ $>\alpha$-tocopherol $>$ BHT. The results demonstrate the electron donor properties of $S$. hortensis extracts for neutralizing free radicals by forming stable products. The results were in accordance with Prasad et al. ${ }^{16}$. They reported that the antioxidant activity of Cinnamomum species may involve other mechanisms in addition to those of reductones.

Table-2 shows that the $\mathrm{EC}_{50}$ values of reducing power for the acetone, EtOH and water extracts were 29.28 $\pm 3.15,32.09$ \pm 1.64 and $42.63 \pm 3.26 \mu \mathrm{g} / \mathrm{mL}$, respectively.

Iron(II) chelation activity: An important mechanism of antioxidant activity is the ability to chelate/deactivate transition metals, which possess the ability to catalyze hydrogen peroxide decomposition and Fenton-type reactions. Therefore, it was considered of importance to screen the iron(II) chelating ability of extracts ${ }^{20}$. All the extracts had high levels of ferrous ion chelating activity (Fig. 3). Water, EtOH, acetone extracts, ascorbic acid, $\alpha$-tocopherol, BHA and BHT chelated ferrous ions by $93.09 \pm 1.14,90.65 \pm 0.33,91.46 \pm 1.63,91.46 \pm$ $0.06,87.39 \pm 0.37,90.65 \pm 0.12$ and $89.02 \pm 1.29 \%$ at 100 $\mu \mathrm{g} / \mathrm{mL}$, respectively. The sequence for chelating power was water extract $>$ acetone extract $\approx$ ascorbic acid $>$ EtOH extract $\approx$ BHA $>$ BHT $>\alpha$-tocopherol. The iron chelating data measured at different concentrations $(20-100 \mu \mathrm{g} / \mathrm{mL})$ suggested that ferrous ion chelating effects of all the extracts of S. hortensis would be somewhat beneficial to protect against oxidative damage. Similarly, Ozsoy et al. ${ }^{21}$, reported that water, methanol and ethyl acetate extracts of Amaranth vegetable showed excellent chelating ability.

From the estimated $\mathrm{EC}_{50}$ values, defined as the concentration of extract required to chelate $50 \%$ of the available iron(II), it can be seen that the most effective iron(II) chelating extract was water $(14.03 \pm 1.03 \mu \mathrm{g} / \mathrm{mL})$, followed by the EtOH $(18.35 \pm 2.44 \mu \mathrm{g} / \mathrm{mL})$ and acetone extracts $(24.46 \pm 1.92 \mu \mathrm{g} /$ $\mathrm{mL}$ ), in decreasing order. The acetone extract showed less chelation activity than BHA (14.93 \pm 0.25$)$, BHT (20.14 \pm 1.09), $\alpha$-tocopherol $(16.01 \pm 0.06)$ and ascorbic acid (17.09 \pm $0.7)$.

Hydrogen peroxide radical scavenging activity: Hydrogen peroxide itself is not very reactive, but it can sometimes be toxic to cells, since it may give rise to hydroxyl radicals inside the cell ${ }^{22}$. Extracts from $S$. hortensis were capable of scavenging hydrogen peroxide in a concentrationdependent manner $(20-100 \mu \mathrm{g} / \mathrm{mL})$. The hydrogen peroxide scavenging activities of water extract $(78.89 \pm 1.3 \%), \mathrm{EtOH}$ extract $(81.77 \pm 3.19 \%)$ and acetone extract $(66.22 \pm 0.04 \%)$ were lower than that of BHA $(88.87 \pm 0.07 \%)$, ascorbic acid 


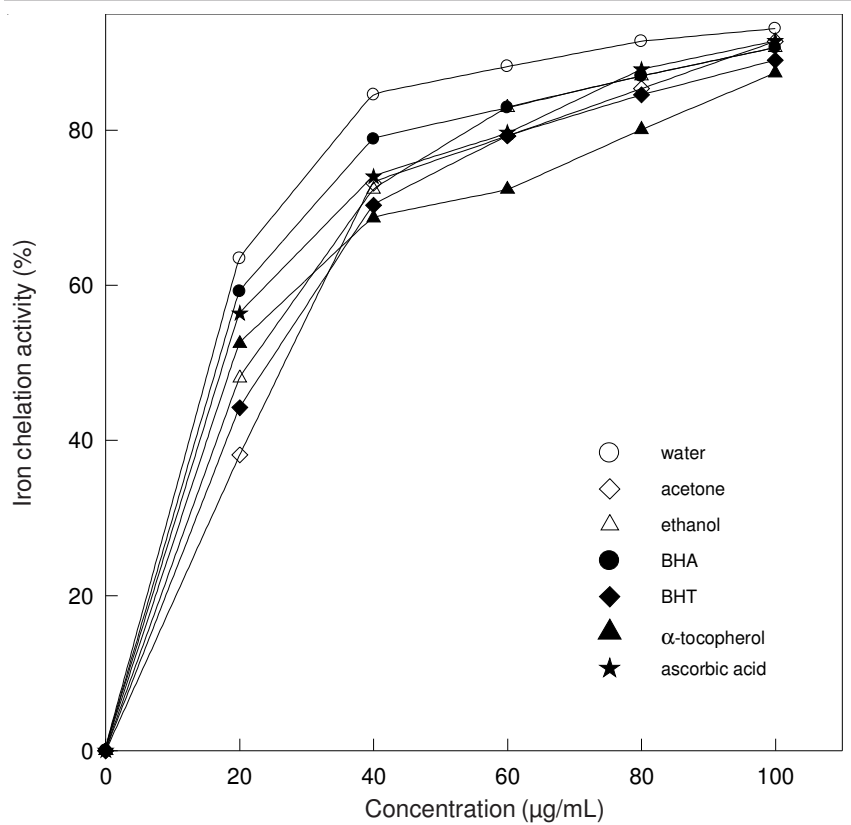

Fig. 3. Metal chelating effect of different concentrations of $S$. hortensis extracts. $\alpha$-Tocopherol, ascorbic acid, BHA and BHT were used as reference antioxidants. Values are means $\pm \operatorname{SD}(n=3)$

$(88.68 \pm 4.57 \%), \alpha$-tocopherol $(88.29 \pm 3.42 \%)$ and BHT $(86.76 \pm 2.42 \%)$ at $100 \mu \mathrm{g} / \mathrm{mL}$ (Fig. 4). The scavenging abilities on hydrogen peroxide were in descending order of $\mathrm{BHA} \approx$ ascorbic acid $\approx \alpha$-tocopherol $>$ BHT $>$ EtOH extract $>$ water extract $>$ acetone extract.

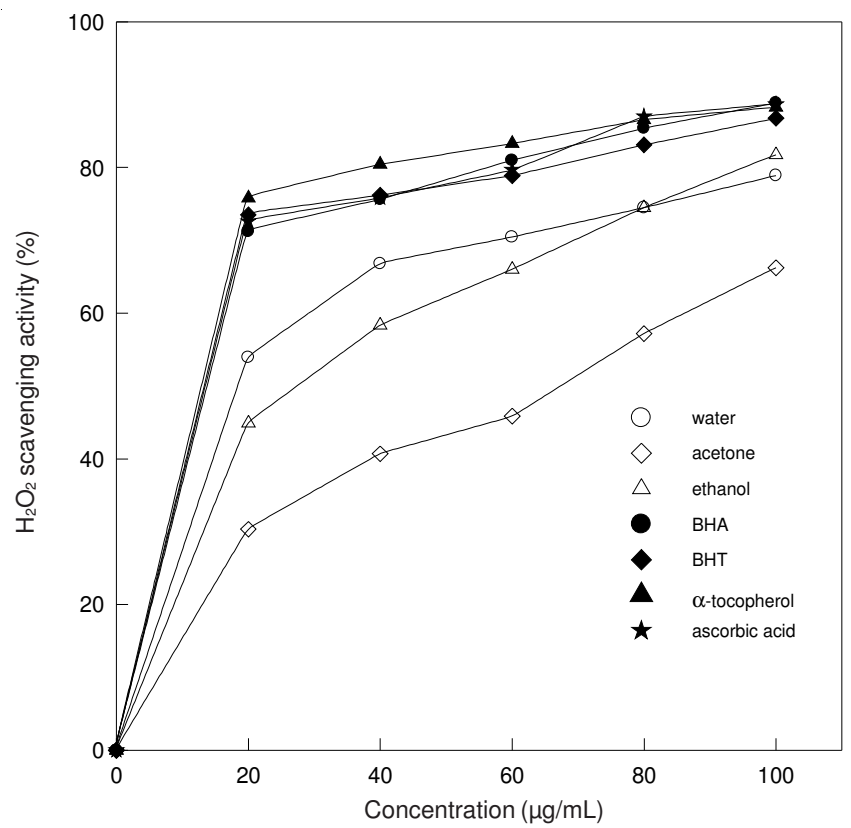

Fig. 4. Hydrogen peroxide scavenging activity of of S. hortensis extracts. $\alpha$-Tocopherol, ascorbic acid, BHA and BHT were used as reference antioxidants. Values are means \pm SD $(n=3)$

The concentrations of acetone, EtOH and water extracts needed for $50 \%$ inhibition $\left(\mathrm{EC}_{50}\right)$ were found to be $24.46 \pm$ $3.51,18.77 \pm 1.74$ and $13.81 \pm 4.28 \mu \mathrm{g} / \mathrm{mL}$, respectively, whereas $11.99 \pm 3.26 \mu \mathrm{g} / \mathrm{mL}$ was needed for $\alpha$-tocopherol.

Superoxide radical scavenging activity: Superoxide is a reactive oxygen species, which can cause damage to the cells and DNA leading to various diseases. It was, therefore, proposed to measure the comparative interceptive ability of the antioxidant extracts to scavenge the superoxide radical ${ }^{23}$. S. hortensis extracts exhibited excellent superoxide anion scavenging activity. At $100 \mu \mathrm{g} / \mathrm{mL}$, the superoxide scavenging activities of water extract, EtOH extract, acetone extract, BHA, BHT, tocopherol and ascorbic acid were $90.83 \pm 2.35,61.11$ $\pm 0.08,80.56 \pm 1.96,97.22 \pm 3.41,97.22 \pm 0.14,84.72 \pm 3.12$ and $81.94 \pm 0.43$, respectively, with $\mathrm{BHA} \approx \mathrm{BHT}>$ water extract $>\alpha$-tocopherol $>$ ascorbic acid $>$ acetone extract $>$ EtOH extract (Fig. 5). It was reported that the superoxide anion scavenging activity could be due to the action of a free hydroxyl group of phenolic compounds. Furthermore, flavonoid molecule with polyhydroxylated substitution on ring $\mathrm{A}$ or $\mathrm{B}$ and $\mathrm{a}$ free 3-hydroxyl substitution could present the superoxide scavenging activity ${ }^{24}$.

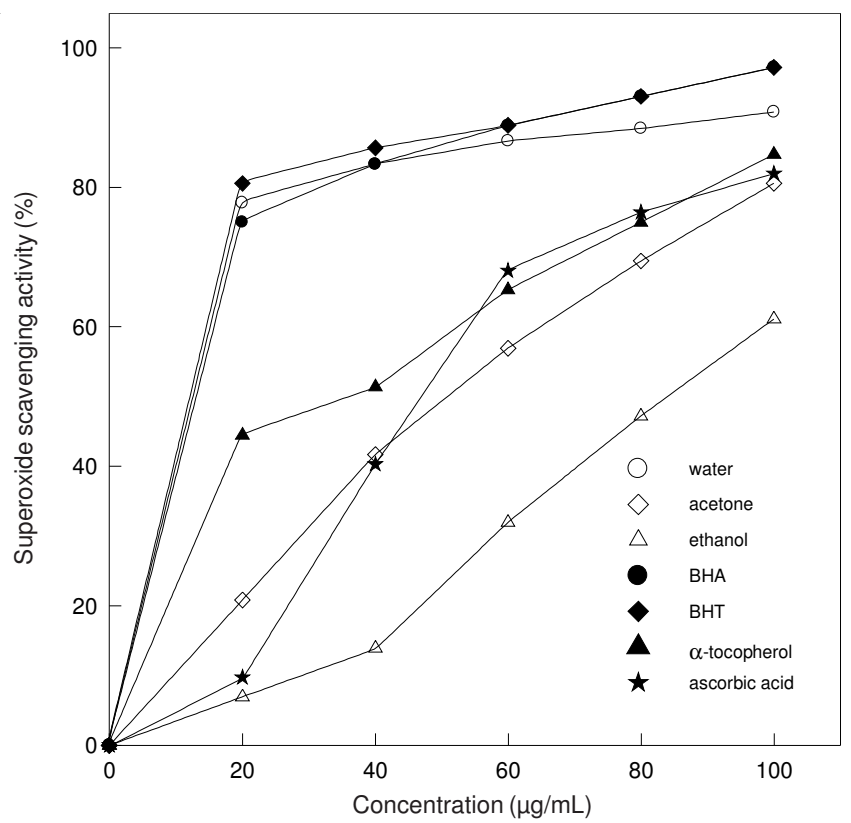

Fig. 5. Superoxide anion radical scavenging activity of $S$. hortensis extracts. $\alpha$-tocopherol, ascorbic acid, BHA and BHT were used as reference antioxidants. Values are means \pm SD $(n=3)$

$\mathrm{EC}_{50}$ values of acetone, $\mathrm{EtOH}$ and water extracts on superoxide radical scavenging activity were found to be 40.09 $\pm 0.17,58.56 \pm 1.04$ and $11.37 \pm 1.66 \mu \mathrm{g} / \mathrm{mL}$, respectively, whereas the $\mathrm{EC}_{50}$ value of $\alpha$-tocopherol was found to be 19.85 $\pm 1.74 \mu \mathrm{g} / \mathrm{mL}$ (Table-2).

Activity determination by ferric thiocyanate method: The ferric thiocyanate method measures the amount of peroxide, which is the primary product of oxidation produced during the initial stages of oxidation. All the extracts of S. hortensis showed a significant total antioxidant activity. The total antioxidant activity of water extract $(46.7 \%)$, EtOH extract $(56.4 \%)$ and acetone extract $(54 \%)$ at $60 \mu \mathrm{g} / \mathrm{mL}$ was higher than those of a-tocopherol (29\%) and ascorbic acid (30.5\%). The sequence for total antioxidant activity was EtOH extract $>$ acetone extract $>$ water extract $>$ ascorbic acid $>\alpha$-tocopherol (Fig. 6). The total antioxidant capacity of plant extract may be attributed to their chemical composition and phenolic acid content. 


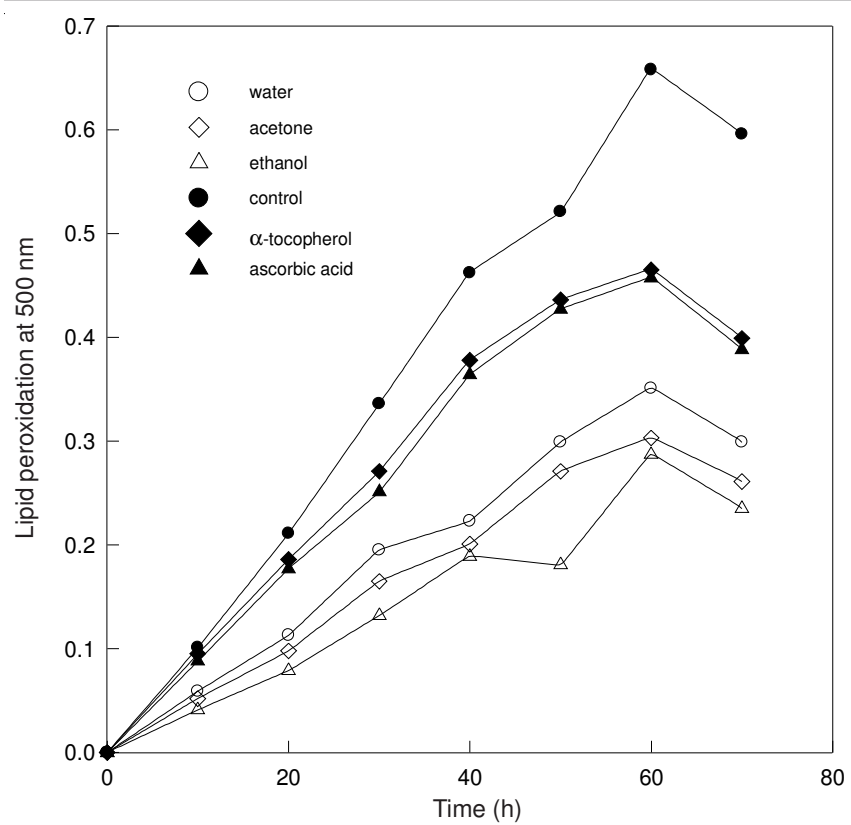

Fig. 6. Inhibition (\%) of lipid peroxidation of S. hortensis extracts. Ascorbic acid and $\alpha$-tocopherol were used as reference antioxidants

\section{Conclusion}

Water could extract the highest concentration of antioxidant compounds (polyphenols and flavonoids) from $S$. hortensis in this investigation; this extract also showed higher antioxidant activity than those extracted by ethanol or acetone. These results reveal that $S$. hortensis flowers and leaves, generally regarded as a disposable byproduct, has potential for exploitation to promote human and animal health.

\section{Abbreviations}

NADH, nicotinamide adenine dinucleotide; BHA, butylated hydroxyanisole; BHT, butylated hydroxytoluene; NBT, nitroblue tetrazolium; PMS, phenazine methosulfate; DPPH, 1,1-diphenyl-2-picrylhydrazyl; ferrozine, 3-(2-pyridyl)-5,6bis(4-phenyl-sulfonic acid)-1,2,4-triazine; Tween-20, polyoxyethylenesorbitan monolaurate; TCA, trichloroacetic acid; EtOH, ethanol.

\section{ACKNOWLEDGEMENTS}

This study was supported by Trakya University Research Foundation (Project No: 2008/113).

\section{REFERENCES}

1. B. Halliwell, Cardiovascular Res., 73, 341 (2007).

2. J. Kubola and S. Siriamornpun, Food Chem., 110, 881 (2008).

3. S.M. Mohsen and A.S.M. Ammar, Food Chem., 112, 595 (2009).

4. Y. Yesiloglu and L. Sit, Spectrochim. Acta A, 95, 100 (2012).

5. H.O. Boo, B.G. Heo, S. Gorinstein and S.U. Chon, Plant Sci., 181, 479 (2011).

6. K. Slinkard and V.L. Singleton, Am. J. Enol. Vitic., 28, 49 (1977).

7. J. Wang, X. Yuan, Z. Jin, Y. Tian and H. Song, Food Chem., 104, 242 (2007).

8. K. Shimada, K. Fujikawa, K. Yahara and T. Nakamura, J. Agric. Food Chem., 40, 945 (1992).

9. M. Oyaizu, Jap. J. Nutr., 44, 307 (1986).

10. K.D. Dastmalchi, H.J.D. Doeman, P.P. Oinonen, Y. Darwis, I. Laaso and R. Hiltunen, LWT-Food Sci. Technol., 41, 391 (2008).

11. R.J. Ruch, S.J. Cheng and J.F. Klaunig, Carcinogenesis, 10, 1003 (1989).

12. Q. Liu, G. Zhu and P. Huang, Zhongguo Zhong Yao Za Zhi, 161, 50 (1991).

13. H. Mitsuda, K. Yuasumoto and K. Iwami, J. Soc. Nutri. Food Sci. (Japan), 19, 210 (1996)

14. S. Selappan, C.C. Akoh and G. Krewer, J. Agric. Food Chem., 50, 2432 (2002).

15. S. Shukla, A. Mehta, V.K. Bajpai and S. Shukla, Food Chem. Toxicol., 47, 2338 (2009).

16. K.N. Prasad, B. Yang, X. Dong, G. Jiang, H. Zhang, H. Xie and Y. Jiang, Innov. Food Sci. Emerg., 10, 627 (2009).

17. D.B. Min, In eds.: C.C. Akoh and D.B. Min, Oxidation of Edible Oil in Food Lipids, Chemistry, Nutrition and Biotechnology, Marcel Dekker, New York, pp. 283-296.

18. K.N. Prasad, S. Divaka, G.R. Shivamurthy and S.M. Aradhya, J. Sci. Food Agric., 85, 1461 (2005).

19. M.R. Bhandari and M. Kawabata, Food Chem., 88, 163 (2004).

20. R. Manian, N. Anusuya, P. Siddhuraju and S. Manian, Food Chem., 107, 1000 (2008).

21. N. Ozsoy, T. Yilmaz, O. Kurt, A. Can and R. Yanardag, Food Chem., 116, 867 (2009).

22. B. Halliwell, Am. J. Med., 91, 14 (1991).

23. T. Vani, M. Rajani, S. Sarkar and C.J. Shishoo, Int. J. Pharmacog., 35, 313 (1997).

24. P. Siddhuraju, P.S. Mohan and K. Becker, Food Chem., 79, 61 (2002). 